\title{
RESEARCH
}

Open Access

\section{Knowledge and interactions of the local community with the herpetofauna in the forest reserve of Quininí (Tibacuy- Cundinamarca, Colombia)}

Juan Camilo Ríos-Orjuela ${ }^{1,2^{*}}$, Nelson Falcón-Espitia ${ }^{3,4}$, Alejandra Arias-Escobar ${ }^{4}$, María José Espejo-Uribe ${ }^{5}$ and Carol Tatiana Chamorro-Vargas ${ }^{4}$

\begin{abstract}
Background: The study of human-nature relationship has made possible to understand the life dynamics of the communities and the biodiversity with which they cohabit. Although there has been a rise of ethnobiological studies over the last decade, little is known about human interaction with herpetofauna in South America and Colombia. In this work, we analyzed the knowledge, perception, and interaction of a local community located in the forest reserve of Quininí (RFPCQ) in Cundinamarca (Colombia), concerning to the herpetofauna that inhabits the area.
\end{abstract}

Methods: We performed semi-structured surveys containing 30 questions categorized into three groups: academic knowledge (1), use and cultural beliefs (2), and interactions (3) related to the herpetofauna that occurs in the region. The obtained data in question groups 1 and 2 are presented as a qualitative summary. For the question group 3, we assigned the answers to a hostility value according to the possible reaction of each individual interviewed in a hypothetical encounter with the herpetofauna and built tendency charts in order to see the positive or negative reactions due to the birthplace (urban/rural) and gender (male/female).

Results: The community recognized the presence of amphibians and reptiles that cohabit their space, as well as their potential habitats. Besides, the role of herpetofauna was recognized in the magical/religious traditions for some inhabitants of the region, mainly associated with the fate and cure of chronic diseases. In general, the perception of amphibians and reptiles varied according to the origin and gender of the people, which tend to have a more positive perception of reptiles than compared to amphibians in most cases.

(Continued on next page)

\footnotetext{
* Correspondence: jcrioso@unal.edu.co

${ }^{1}$ Museu de Zoologia da Universidade de São Paulo, Avenida Nazaré 481, Ipiranga, São Paulo, SP CEP 04263-000, Brazil

${ }^{2}$ Grupo de Morfología y Ecología Evolutiva, Instituto de Ciencias Naturales,

Universidad Nacional de Colombia, Sede Bogotá, Apartado, 7495 Bogotá

D.C., Colombia

Full list of author information is available at the end of the article
}

(c) The Author(s). 2020 Open Access This article is licensed under a Creative Commons Attribution 4.0 International License, which permits use, sharing, adaptation, distribution and reproduction in any medium or format, as long as you give appropriate credit to the original author(s) and the source, provide a link to the Creative Commons licence, and indicate if changes were made. The images or other third party material in this article are included in the article's Creative Commons licence, unless indicated otherwise in a credit line to the material. If material is not included in the article's Creative Commons licence and your intended use is not permitted by statutory regulation or exceeds the permitted use, you will need to obtain permission directly from the copyright holder. To view a copy of this licence, visit http://creativecommons.org/licenses/by/4.0/ The Creative Commons Public Domain Dedication waiver (http://creativecommons.org/publicdomain/zero/1.0/) applies to the data made available in this article, unless otherwise stated in a credit line to the data. 
(Continued from previous page)

Conclusions: Although there was a general lack of knowledge on the part of the inhabitants of the RFPCQ about the biological and ecological aspects of herpetofauna, the population recognized the basic information about the habitats of these animals within the reserve area. There is a wide variety of uses of amphibians and reptiles in traditional medicine. Greater efforts should be made in the transmission and dissemination of knowledge about the ecological functions of herpetofauna.

Keywords: Ancestral knowledge, Ethnoherpetology, Herpetofauna, Interactions, Local communities

\section{Background}

Human communities have established a close relationship with the herpetofauna with which they cohabit, based on the use and understanding of amphibians and reptiles [1-5]. Thereby, the ethnoherpetology (as an integral part of ethnobiology) studies traditional knowledge acquired from relationships between humanherpetofauna and interactions themselves, such as how a social group classifies and identifies different amphibians and reptiles species and their traditional uses [6].

Colombia is one of the most diverse countries of the world regarding herpetofauna species; currently, 616 species of reptiles and 835 species of amphibians $[7,8]$ have been identified in Colombia, with 115 and 367 endemic species, respectively [9]. Considering this diversity, it is important to understand local communities' perceptions about the species with whom they share their territory to reveal information about the historic relationship of these communities with nature in the region. This can be the base for establishing conservation plans at local and regional scale, involving academics, politics, and local communities [10].

For some years now, ethnozoological studies have been conducted in Colombia that focused mostly on reptiles with high commercial usage, e.g., Trachemys callirostris (Gray, 1856), Iguana iguana (Linnaeus, 1758), Boa constrictor Linnaeus, 1758 and Tupinambis teguixin (Linnaeus, 1758), among others [11-14]. Nevertheless, there is little information about the use and perception of herpetofauna as a biological group, which is concerning when the high biological diversity of Colombia and Andes mountains is taken into account $[9,15,16]$. Thus, efforts to obtain information about the fauna and its interactions within the habitat become relevant where ethnobiological studies play a fundamental role in understanding the recent ecosystem dynamics, such as changes in the vegetal covertures and biodiversity among others [17, 18]. The Reserva Forestal Protectora Cerro Quinini (RFPCQ) forest reserve is a conservation area located in the Sumapaz province (Cundinamarca, Colombia), which is one of the most important biological corridors not only for the region but also for the eastern Andes, known as the Chingaza-SumapazGuerrero corridor [19]. Besides, records of archeological remains, such as petroglyphs and passage routes, associated with the Panche community, an indigenous culture that inhabited this territory in pre-colonial times, are known [20, 21].

Due to its cultural and biological importance, RFPCQ has been the focus of the studies in diversity [22-27], ecology [28-30], anthropology [20, 21, 3133 , rural development, and innovation in production systems [34, 35], among others. Although most of the research associated with RFPCQ remains unpublished literature, it has actively involved community participation, which allowed them to appropriate environmental aspects. These initial approaches to environmental problems constitute a fundamental basis for understanding the current dynamics of the ecosystems to design a conservation plan where the community has a direct role.

Taking this into account, our aim is to evaluate the knowledge and perception of the RFPCQ community about the herpetofauna in three different aspects: (1) academic knowledge, (2) use and cultural beliefs, and (3) human-herpetofauna interactions. In this way, we propose an initial approach to the relationship between the community and amphibians and reptile species that inhabit their territory.

\section{Methods \\ Study area}

The Reserva Forestal Protectora Cerro Quinini (RFPCQ) forest reserve is located in Tibacuy, Nilo and Viotá municipalities (Cundinamarca, Colombia) (Fig. 1), between 1050 and $2133 \mathrm{~m}$ above sea level on Eastern Andes range. The region has a predominantly temperate climate, with an average annual temperature of $19.2{ }^{\circ} \mathrm{C}$ and a bimodal rainfall pattern [18]. With an approximate area of 1947 ha, it is one of the most extensive conservation areas in the Cundinamarca department [19].

According to the classification of Holdridge (1947) [36], the RFPCQ is located in the life zones of lower mountain moist forest and, to a lesser extent, lower mountain dry forest. Despite its protected area status, about $90 \%$ of the land associated with the RFPCQ are private properties, mainly with mixed crops, grazing areas, and coffee crops, being the largest [18, 35, 37, 38]. 


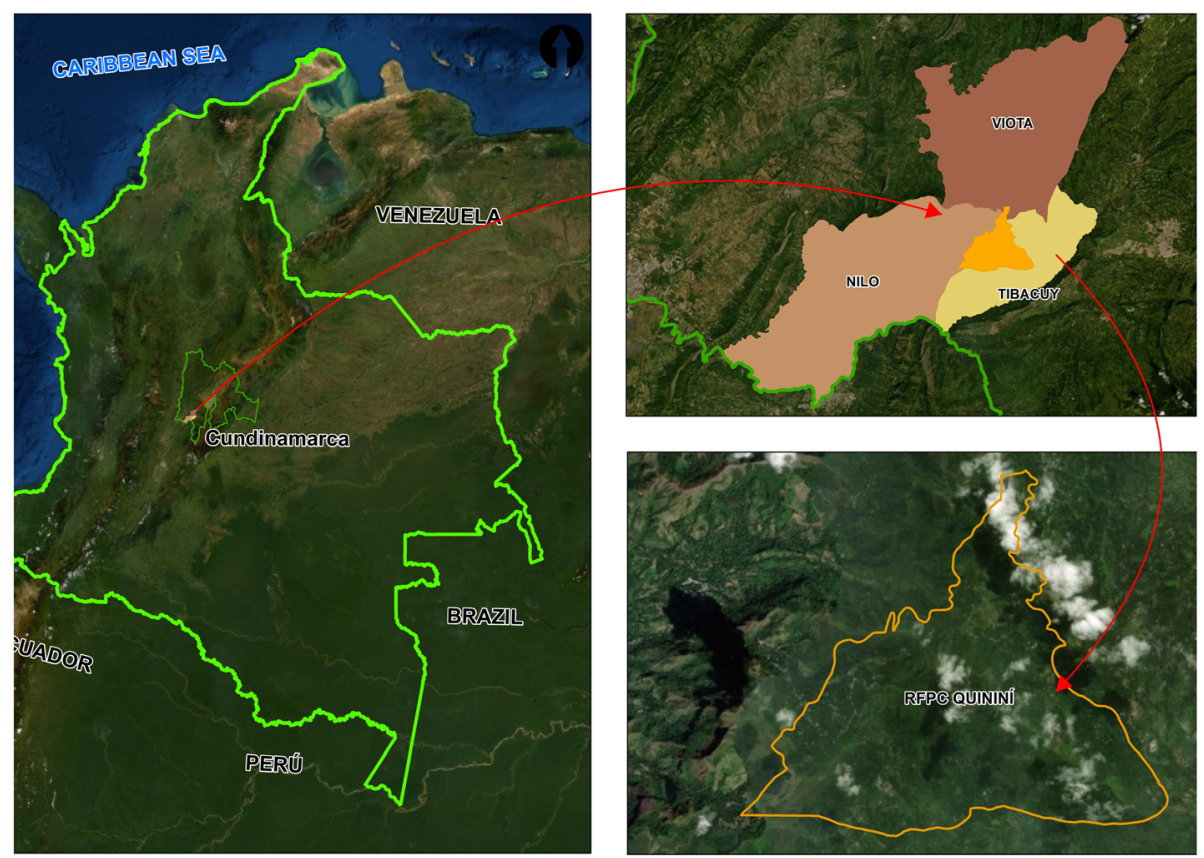

Fig. 1 Localization of Reserva Forestal Protectora Cerro Quininí (RFPCQ) forest reserve

The area was declared as a protected forest reserve in 1987 to conserve its renewable natural resources and environment by request of the people inhabiting the area, mainly because of essential water springs, which supply the region [39].

\section{Data collection}

Following Margoluis and Salafsky (1998) and Drumond et al. (2009) [40, 41], we made 61 semi-structured surveys during April 2016 and June 2019 with randomly selected respondents in the communities of Cumaca inspection, Albania, and La Vuelta villages (Tibacuy municipality), gathering information from people in urban as well as rural areas near the RFPCQ. We were unable to extend our surveys to more people due to the large distance between homes in the rural area and its low density of inhabitants.

Each survey had 30 questions of which 12 were related to general topics of amphibians and 18 were about general topic reptiles. We collected demographic information such as name, gender, age, occupation, birthplace, and education level in the following categories: illiterate, fundamental basic education, secondary education, and university education. Following the International Society of Ethnobiology Code of Ethics (2006) [42], before we started each survey, the project aims were presented and the consent to use the information was requested from each person. The complete model of the survey is available as an additional file (see Additional file 1).
Questions were categorized into three groups: academic knowledge (1), use and cultural beliefs (2), and interactions (3). The first group refers to questions related to the biology and ecology of the herpetofauna; in the second group, the questions were related to the ancestral knowledge of the community about the local herpetofauna and the third group contains questions about perception and human-herpetofauna interactions in daily activities.

\section{Data analysis}

The obtained data in question groups 1 and 2 are presented as a qualitative summary. For the data concerning question group 3 , answers were assigned to a hostility value according to the possible reaction of the individual interviewed in a hypothetical encounter with herpetofauna. In this way, interaction with amphibians was classified as a negative (hostile) behavior when respondents suggested trying or scare the animal; neutral behaviors when observing the animal and staying still or moving away; and positive behaviors when transporting the animal to a nearby body of water. Interaction with reptiles was classified in the same way, except for the behavior to remain still or move away, which was considered positive.

Demographic information obtained from the surveys was organized in categories for each variable. Age was categorized into three groups: (a) young people (14-26 years old), (b) adults (27-51 years old), and elder (52-83 years old). Besides, the data obtained in the urban area 
of Cumaca were considered as "urban," whereas the data obtained in the villages of Albania and La Vuelta were considered as "rural."

We also built trend-charts using data from question group 3 to see the positive or negative reactions due to the birthplace (urban/rural) and gender (male/female). We selected birthplace and gender because the initial analysis showed that these two factors had the biggest expected difference in the population.

To compare the samples, a qualitative analysis between the groups was used to assess differences in the answers given the birthplace, education level, and gender; this was done for questions from group 1 (academic knowledge) and 2 (cultural uses and beliefs). The localization map of the study area was built with ArcGIS 10.5 [43].

\section{Results}

We surveyed 61 respondents, aged 14-83 with a balanced gender ratio (1:1). Table 1 shows the distribution of the population surveyed in the education level completed and occupation categories.

\section{Academic knowledge}

Regarding amphibians, 33 people (more than half of the respondents) classified frogs and toads within this group; six people classified them as reptiles, whereas 22 people said they did not know. Also, they recognized water reserves as a habitat for amphibians, as well as its importance in their life and reproduction cycles. However, only eight people associated amphibian reproduction with soft egg posture and the presence of larval stages. Most respondents described wet soil, plants with water

Table 1 Distribution of the population surveyed into completed education and occupation categories

\begin{tabular}{llll}
\hline & Female & Male & Total \\
\hline Education level & 16 & 16 & 32 \\
High school & 8 & 10 & 18 \\
Primary school & 4 & 2 & 6 \\
College degree & 1 & 1 & 2 \\
Graduate degree & 1 & 0 & 1 \\
Technical studies & 0 & 1 & 1 \\
Illiterate & 0 & 1 & 1 \\
Unanswered & & & \\
Occupation & 8 & 8 & 16 \\
Employee, merchant or independent & 7 & 9 & 16 \\
Student & 4 & 10 & 14 \\
Agriculture and land management work & 4 & 3 & 14 \\
Housework and other trades & 11 & 1 & 1 \\
$\quad$ Unemployed & 0 &
\end{tabular}

reserves, and crops as a preferred habitat for frogs and toads. Regarding their ecological function, respondents recognized the importance of amphibians as pest controllers and associated their presence with the reduction of mosquitoes' abundance. Although most of the respondents (43 people) recognized the existence of poisonous frogs, only two persons stated that it is possible to find them in Colombia.

As for reptiles, 36 people classified lizards and snakes within this group, three persons classified them as amphibians, whereas 22 people said they did not know. According to the surveyed population, the main habitats of reptiles are associated with tall trees, crops, grasslands, and wet soils. Although the role reptiles play within the ecosystem is unclear, nine people knew that they can act as pest controllers.

Fifty-three of the respondents acknowledged that there are venomous snakes in the region. However, only 21 people of the population surveyed said they knew the medical treatment associated with snake bites, such as the use of antiofidic serum and the referral to the municipal medical services.

\section{Use and cultural beliefs}

For 39 respondents, amphibians are not part of their cultural or magical-religious beliefs, while three of them said they did not know. On the other hand, 19 people of the surveyed population described cultural beliefs and uses in traditional medicine associated with this group (Table 2). Twenty-two people of the surveyed population perceive amphibians as dangerous animals, whereas 13 people describe them as causes of skin diseases such as sores, rash, allergies, inflammations, and even necrosis.

As for reptiles, 29 of the respondents did not associate this group with their cultural or magical-religious beliefs, whereas three persons said they did not know. Twenty-nine of the respondents described beliefs associated with luck and use in traditional medicine. Fifty-four people of the population surveyed perceive reptiles as dangerous animals and 17 people associate them with the transmission of diseases such as leprosy, burns, and other skin problems.

\section{Interaction}

The tendency chart suggests a possible correlation between the demographic variables of birthplace and gender, within the interaction with amphibians. Compared to people living in the rural area, people living in the urban area are more likely to have a hostile reaction in a possible encounter with an amphibian. Also, women tend to have a more negative behavior towards amphibians than to reptiles (Fig. 2).

In contrast, there is only one possible incidence for the gender variable in reptile interaction, where men are more likely to react hostile to an encounter with reptiles than 


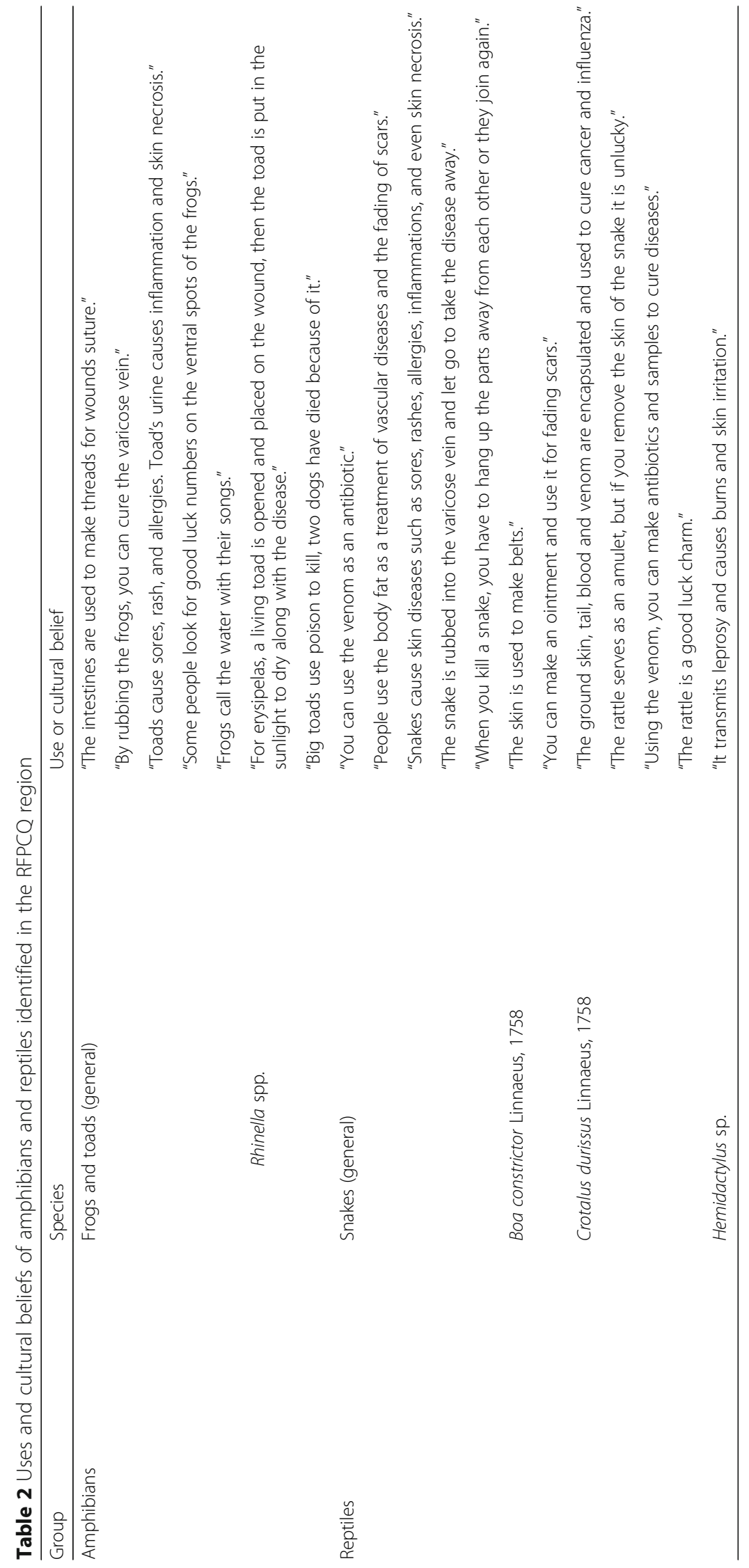




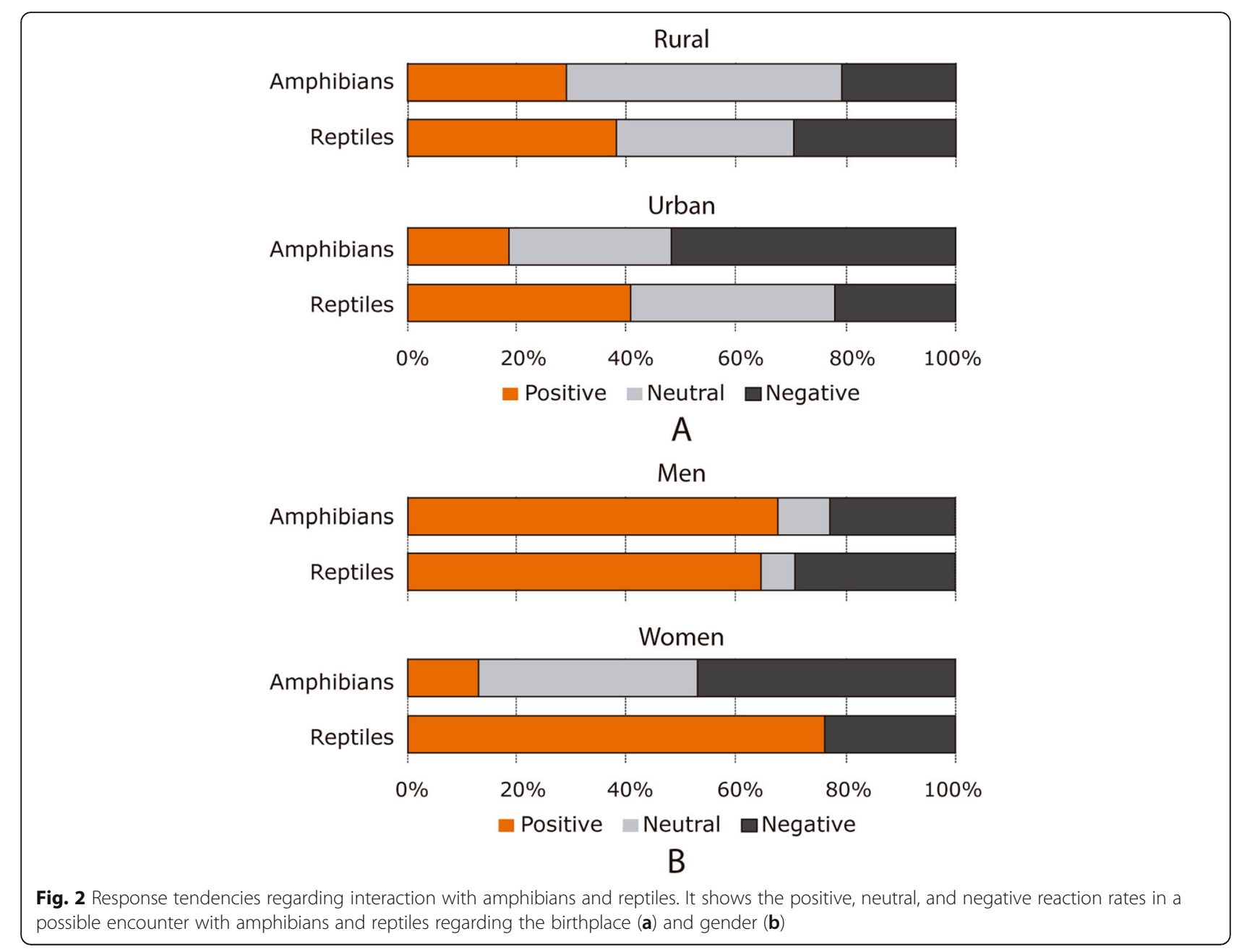

women. In addition, there were no neutral behaviors by women in this variable, being the majority positive reactions (23 of the respondents) and the remaining ones negative (seven women). There was no apparent relationship between age and the interaction with amphibians and reptiles.

For most people surveyed (34 people) the abundance of herpetofauna in the RFPCQ has decreased in recent years, especially amphibians. Twelve people of the surveyed population expressed that abundance has increased, whereas ten persons state that it has remained the same. Finally, five persons said they did not perceive a change. Respondents described agricultural activities, chemical fumigation, deforestation, and water pollution as possible current impacts on the amphibian and reptile community in the region. All respondents recognized the importance of generating conservation programs and sustainable usage of the habitat to protect the herpetofauna in the region.

\section{Discussion}

\section{Academic knowledge}

The surveyed population recognizes the existence of amphibians and reptiles in the region, although little is known about general aspects of their biology and the ecological role of this group, for example, the ability of reptiles to prevent insects pests, such as mosquitoes, or control of populations of other animals such rodents or even snakes [44, 45]. However, the inhabitants properly recognize the potential habitats of these animals, which could help identify priority conservation areas [10, 41, 46, 47].

The local community recognizes the existence of venomous snakes in the region, although it tends to ignore the existence of non-venomous species. This may be due to the association of the body morphology of these animals with risk factors, generally associating serpentiform animals as dangerous; given the evolutionary conditioning of human species [48], which has also been recorded in other primates [49].

Although the population surveyed is aware of the possibility of an ofidic accident, there is a general lack of knowledge about the protocols to follow in case of snake bites, as the use of anti-ofidic serum is uncommon. This lack of knowledge amplifies the human-snake conflict since the most widespread action to avoid ophidian 
accidents is killing snakes (even non-venomous), making this one of the main threats to the ophidians' population in Colombia [50].

\section{Use and cultural beliefs}

Nearly half of the people surveyed associated reptiles (exclusively snakes) as a part of ancestral culture and traditional medicine, whereas for amphibians this association was lower. We propose two reasons as an explanation: (1) As in other regions of Latin America, given the traditional representation of power and the strong ligation of snakes with magical-religious beliefs, the development of a worldview that linked snakes to luck and uses in traditional medicine is more common, based on the cure through the power and the spirit that snakes represent even when this group of animals is considered as dangerous for the people in general $[2,45]$. (2) Since amphibians are mainly nocturnal, a meeting with people in their daily activities is less common. This has resulted in less strong interaction and a minor influence on the worldview of the inhabitants of the region. Although Panche indigenous communities made drawings of amphibians and associated them with water [20], it seems that these traditions were not maintained over time by the current inhabitants.

A third of the population surveyed perceives amphibians as dangerous and disease-causing animals. The main belief was that skin wounds are caused by urine or secretions of the parotid glands of the toads (Rhinella spp.). Although information on the effect of bufotoxins on human health is scarce [51,52], there are extensive records of intoxication in dogs [53-56] and wild vertebrates [57-59]. This is a problem especially widespread in countries in which this species has been introduced, sometimes causing the death of the animals involved $[54,56]$. However, it is more common to find that toads are avoided due to their physical appearance, which, added to the lack of knowledge about their biology, results in the association of these animals with areas of debris and dirt.

On the contrary, most of the population surveyed perceive reptiles as dangerous animals (54 people), based mainly on the fear of an ophidian accident. Although $47.5 \%$ of the reported cases of poisoning in Colombia correspond to ophidian accidents [60], between 2014 and 2016 only 185 cases of snakebite were reported in the department of Cundinamarca (61 cases on average per year [61];), it is, therefore, one of the departments with fewer reported cases in Colombia $(<2 \%)$. This can indicate that the response of fear towards snakes is more linked to the cultural imprint rather than to the interaction and previous experiences of the inhabitants with snakes in the area.
Despite this, there are several uses of amphibians and reptiles in traditional medicine, such as the use of dissected toads for the cure of varicose veins, shingles (herpetic skin lesion), erysipelas, and other dermal bacterial infections, as well as the use of snakes for the cure of some diseases such as cancer and heart ailments (Table 2). Previous studies have also reported these uses in other Latin American countries [62-64] and other regions of the world $[65,66]$. Besides, in recent decades there has been increasing evidence on the possibility of pharmacological synthesis based on chemical components obtained from secretions, tissue, and venom extracted from amphibians and reptiles [67-70], which shows the correspondence between the use of species in the traditional culture, as well as in current and future applications in medicine.

\section{Interaction}

The response of the rural population towards the interaction with amphibians is dominated by neutral and positive behaviors, which contrasts with the response to the same interaction in the urban population (Fig. 2).

For the rural population, amphibians are a fundamental part of the nocturnal sound ecosystem, which could have a positive impact on the perception of these animals. As the occurrence of amphibians in the urban area is less frequent, people likely develop a negative perception due to the lack of contact. On the contrary, the trend response to interaction with reptiles between the rural and urban population is similar, which could indicate that there is an imprint of information on reptiles that remains more stable between the community and birthplaces.

Despite people's cultural/natural fear towards snakes $[48,71]$, in most cases, the positive behavior in the interaction with reptiles was higher than in the interaction with amphibians. However, this may be due to the difference in the classification of positive and neutral reactions, where the behavior of standing still or moving away is considered neutral for the interaction with amphibians, whereas it is positive for the interaction with reptiles. The above is based on the idea that possible positive behaviors towards reptiles (specifically snakes) do not consider transporting the animal to a safe place, due to its potential danger [71-73].

Men described mostly positive behaviors in response to interaction with amphibians and reptiles, tending to have few neutral behaviors in both groups. This indicates that, although snakes are perceived as dangerous animals, this usually does not lead to defensive behavior that implies the threat of species in the study region, a phenomenon previously reported in other parts of Latin America $[2,45,71,73]$ where the conservation status of 
different species is put at risk by the effect of the controlling hunt and the use of this group of animals with magical-religious purposes. In contrast, women in the surveyed population tend to have more negative behaviors in the interaction with amphibians compared to reptiles. This may be related to the possible danger of snakes, since taking a negative reaction and attacking the animal implies a health risk, which does not occur with amphibians and could make them more susceptible to be attacked.

Although the data provided by this study represent a preliminary approach to the understanding of current human-herpetofauna interactions in the RFPCQ, the implementation of a more direct methodological design is necessary, to test the reactions of people in a controlled environment. These studies are vital as a basis for planning conservation strategies in the region since the interaction of humans with nature directly influences the survival dynamics of current animal populations [64, 74, 75].

\section{Final considerations}

When local communities are empowered with basic knowledge about the species that occur in their region and become active agents of participation for their conservation, management, and preservation, plans are effective [2, 46, 47, 76]. The local population recognizes the importance of preserving and conserving nature, although they are unaware of the fundamental reasons why this type of action should take place. Thus, processes such as deforestation, degradation, and habitat loss caused mainly by human activities such as improper use of land, overexploitation of natural resources, and the exclusivity of land use for agriculture and cattle ranching need to be reassessed $[75,77]$.

In this way, ethnozoological studies become relevant by serving as a bridge that unites the different communities in favor of the conservation of species, making them active agents in all phases of these processes [2]. Studies of this type allow us to give an account not only of which species are used by the communities but also of how they are used, taking into account the impact of this human-animal relationship on the implementation of conservation plans for different species, many of which are used intensively and/or in danger of extinction [5, $64,74,78]$. Furthermore, these studies offer local ecological information on important species, strengthening the discussion about their conservation $[79,80]$ without limiting the access of local communities to fauna and allowing the prioritization of species in such conservation plans, as proposed by Martínez (2013) [81] in the Argentine Chaco region.

Similarly, it is possible to develop conservation plans involving a greater number of actors through ecotourism, which serves as a source of income for local people and as a means of conserving entire ecosystems, using the experience of the communities in the execution of these plans. This practice is known as ethnotourism, which has been gaining strength as a conservation strategy $[82,83]$.

Due to the current way in which science is communicated, with a vast majority of scientific papers not being very informative for local communities, it is common to find only a limited scope of knowledge in local communities, not allowing their participation in decision-making $[2,84]$. Although biology is a discipline that uses rather technical terms, efforts to ensure assertive communication must be prioritized to allow the reduction of sectorization and to make information available to the people most directly related to the natural environment $[45,85]$.

\section{Conclusion}

Although there was a general lack of knowledge on the part of the inhabitants of the RFPCQ about the biological and ecological aspects of herpetofauna, the population recognized the basic information about the habitats of these animals within the area of the reserve, which could help identify possible priority conservation areas.

Most of the population does not associate the herpetofauna with cultural or magical-religious traditions. However, there is a wide variety of uses of amphibians and reptiles in traditional medicine, which are consistent with the information obtained in other regions of Latin America and the world.

In general, the perception of amphibians and reptiles varied according to the origin and gender of the people surveyed, tending to have a more positive perception about reptiles that of amphibians in most cases.

Greater efforts should be made in the transmission and dissemination of knowledge about the ecological functions of herpetofauna, which will contribute to the success of future conservation plans in the area with the local community's participation.

\section{Supplementary information}

Supplementary information accompanies this paper at https://doi.org/10. 1186/s13002-020-00370-8.

Additional file 1. Survey format

Additional file 2. Surveys data

Abbreviations

RFPCQ: "Reserva Forestal Protectora Cerro Quinini" forest reserve; Sp (p): Species

Acknowledgements

We would like to thank the Castillo family, the Quininí farm and the Asociación de Protectores de los Recursos Naturales y del Ambiente de Tibacuy (APRENAT) association for their hospitality, logistic help, and compromise 
with the academic activities at the RFPCQ. Thanks to Felipe Escobar for his help at different stages of the project and revision of the manuscript and to Andrés Olaya for his help in preparing the RFPCQ location map. Also, we want to thank Uber Rozo, Miller Castañeda, Johana Muñoz, Miguel Méndez, Jherandyne Castillo, Juliana Poveda, and Sebastián Pérez for their help in the fieldwork and participation at different stages of the project. To the Grupo estudiantil de Herpetología de la Universidad Nacional de Colombia (HERPETOS UN) and its members for helping us with the fieldwork and the tabulation of the surveys. We thank the Project Management Program (PGP - Bienestar Universitario) and Facultad de Ciencias of Universidad Nacional de Colombia, Sede Bogotá, who financed the field stage and information gathering. Also, thanks to Dr. Martha Calderón, Dr. Adriana Jerez, and our reviewers for their invaluable suggestions.

\section{Authors' contributions}

All authors worked equally on this manuscript. All authors read and approved the final manuscript.

\section{Authors' information}

J. C Ríos-Orjuela is a biologist from the National University of Colombia and an MSc student in systematics and biodiversity at the University of São Paulo. His interests include herpetology and ornithology and his research works include aspects of functional morphology in reptiles, the evolution of neotropical birds, and citizen science education.

N. Falcón-Espitia is a biologist from the National University of Colombia. His interests are based on herpetology and his research works include aspects of morphology in reptiles and ecology.

A. Arias-Escobar is a biologist from the National University of Colombia. Her interests include ecology, morphology, and conservation of amphibians and reptiles and citizen science education.

M. J. Espejo-Uribe is a biologist from the National University of Colombia. Her general interests are ecology and conservation genetics, taking as principal research group amphibians and birds.

C. T. Chamorro-Vargas is a bachelor's student in biology from the National University of Colombia. Her interests are herpetology and ecology, and her research works include aspects of the life history of reptiles and ecoacustics of amphibians.

\section{Funding}

This paper is a part of a project by the student herpetology group of the National University of Colombia (HERPETOS UN). However, no funding was provided by any source to conduct this survey.

\section{Availability of data and materials}

A complete survey model can be found as Additional file 1. Survey format conducted on the inhabitants in the study area.docx.

Data collected from surveys are available in Additional file 2. Surveys data.xlsx.

\section{Ethics approval and consent to participate}

The study conforms to the code of ethics of the International Society of Ethnobiology [42]. Prior informed consent was obtained from all participants before interviews.

\section{Consent for publication}

Not applicable.

\section{Competing interests}

The authors declare that they have no competing interests.

\footnotetext{
Author details

'Museu de Zoologia da Universidade de São Paulo, Avenida Nazaré 481, Ipiranga, São Paulo, SP CEP 04263-000, Brazil. 'Grupo de Morfología y Ecología Evolutiva, Instituto de Ciencias Naturales, Universidad Nacional de Colombia, Sede Bogotá, Apartado, 7495 Bogotá D.C., Colombia. ${ }^{3}$ Laboratorio de Ecología Evolutiva, Departamento de Biología, Facultad de Ciencias, Universidad Nacional de Colombia, Sede Bogotá, Ciudad Universitaria, Bogotá D.C. 11001, Colombia. ${ }^{4}$ Grupo estudiantil de Herpetología, Área curricular de Biología, Facultad de Ciencias, Universidad Nacional de Colombia, Sede Bogotá, Ciudad Universitaria, Bogotá D.C. 11001, Colombia. ${ }^{5}$ Grupo de Biodiversidad y Conservación Genética, Instituto de Genética,
}

Universidad Nacional de Colombia, Sede Bogotá, Ciudad Universitaria, Bogotá D.C. 11001, Colombia.

\section{Received: 15 October 2019 Accepted: 7 April 2020 \\ Published online: 15 April 2020}

\section{References}

1. Gómez G, Reyes S, Solano C, Valadez R. La medicina tradicional prehispánica. Vertebrados terrestres y productos medicinales de tres mercados del Valle de México. Etnobiología. 2005;5:86-98.

2. Alves RRN, Vieira KS, Santana GG, Vieira WLS, Almeida WO, Souto WMS, et al. A review on human attitudes towards reptiles in Brazil. Environ Monit Assess. 2012;184:6877-901.

3. Ceríaco L. Human attitudes towards herpetofauna: The influence of folklore and negative values on the conservation of amphibians and reptiles in Portugal. J Ethnobiol Ethnomed. 2012;8:1-12.

4. Reyna M, García A, Neri E, Alagón A, Monroy R. Conocimiento etnoherpetológico de dos comunidades aledañas a la reserva estatal sierra de Montenegro, Morelos, Mexico. Etnobiología. 2015;13:37-48.

5. Alves R, de Araújo B, Policarpo I, Pereira H, Borges A, Vieira W, et al. Keeping reptiles as pets in Brazil: ethnozoological and conservation aspects. J Nat Conserv [Internet]. Elsevier; 2019;49:9-21. Available from: https://doi.org/ https://doi.org/10.1016/j.jnc.2019.02.002.

6. Albuquerque U, Silva J, Campos J, Sousa R, Silva T, Alves R. The current status of ethnobiological research in Latin America: gaps and perspectives. J Ethnobiol Ethnomed. 2013;9:1-9.

7. Acosta-Galvis A. Lista de los Anfibios de Colombia: Referencia en línea V.09. 2019. https://www.batrachia.com Batrachia, Villa Leyva, Boyacá, Colomb. 2019.

8. Uetz P, Freed P, Hosek J. The reptile database. http://www.reptile-database. org. 2019

9. Andrade G. Estado de conocimientos de la biodiversidad en Colombia y sus amenazas. Consideraciones para fortalecer la interacción ciencia -políica. Rev la Acad Colomb Ciencias Exactas. Físicas y Nat Colomb ciencias. 2011; 35:491-507.

10. Pinto LC, AJDR C, MRS P. Incorporando o conhecimento ecológico local na conservação dos lagartos da serra do ouro branco, Minas Gerais, Brasil. Biosci J. 2015;31:613-22.

11. De la Ossa-Lacayo A, De La Ossa VJ. Utilización de fauna silvestre en el área rural de Caimito, Sucre, Colombia. Rev Colomb Cienc Anim - RECIA. 2012;4: 46-58.

12. De la Ossa-Lacayo A, De la Ossa J. Apuntes etnozoológicos: Montes de María, Sucre, Colombia. Rev Colomb Cienc Anim. 2015;7:191-6.

13. Ardila-Marulanda M, De La Ossa VJ, De la Ossa-Lacayo A. Uso de quelonios continentales en el golfo de Morrosquillo, Sucre, Colombia. Rev Colomb Cienc Anim - RECIA. 2016;8:361-7.

14. Valencia-Parra E, De La Ossa VJ. Patrones de uso de fauna silvestre en el bajo río San Jorge, Sucre, Colombia. Rev Colomb Cienc Anim - RECIA. 2016; 8:276-82.

15. Kattan GH, Franco P, Rojas V, Morales G. Biological diversification in a complex region: a spatial analysis of faunistic diversity and biogeography of the Andes of Colombia. J Biogeogr. 2004;31:1829-39.

16. Rangel O. La biodiversidad de Colombia. Palimpsestvs [Internet] 2005;5:292304. Available from: http://www.bdigital.unal.edu.co/14263/1/3-8083-PB.pdf.

17. Alves RR, Silva JS, da Silva Chaves L, Albuquerque U. Ethnozoology and animal conservation. In: Alves RR, Albuquerque U, editors. Ethnozoology Anim our lives. 1st ed. London, UK.: Academic Press, Elsevier; 2018. p. 481492.

18. Corporación Autonoma Regional de Cundinamarca. Diagnóstico, prospectiva y formulación de la cuenca hidrográfica del río Sumapaz. Plan de Manejo y Ordenamiento de la Cuenca (POMCA) del río Sumapaz. Bogotá D.C; 2016.

19. Sguerra S, Bejarano P, Rodríguez O, Blanco J, Jaramillo O, Sanclemente G. Corredor de Conservación Chingaza -Sumapaz -Guerrero: Resultados del Diseño y Lineamientos de Acción. 1st ed. Sguerra S, editor. Conservación Internacional Colombia y Empresa de Acueducto y Alcantarillado de Bogotá ESP: Bogotá, Colombia; 2011.

20. Arango J. Contribución al estudio de la historia de los Panches. Excavaciones arqueológicas en la zona del Quininí. Departamento de Antropología, Universidad de los Andes, Bogotá.; 1974. 
21. Martínez D, Botiva A. Manual de arte rupestre de Cundinamarca. 2nd ed. Bogotá D.C: Instituto Colombiano de Antropología e Historia, Grupo de Arqueología y Patrimonio; 2004.

22. Escobar N. Diagnóstico de la composición florística asociada a actividades agropecuarias en el Cerro Quininí (Colombia). Rev Ciencias Agropecu. 2013; 1:1-19.

23. Ordoñez J, Montes-Pulido C. Orquideoflora de la Reserva Natural Quininí, Tibacuy, Cundinamarca, Colombia y consideraciones para su bioprospección. Orquideología. 2013;30:18-33.

24. Alonso-Ortiz C, Ariza-Marín E, Galvis-Jiménez S, Lagos-Oviedo J, Mariño J, Martínez-Torres D, et al. Artropofauna de La Reserva Agroforestal Cerro de Quininí Tibacuy-Cundinamarca. Bogotá D.C; 2016.

25. Beltran J, Diaz Y. Identificación de los géneros de orquídeas presentes en la reserva natural del Quininí en el municipio de Tibacuy. Cundinamarca: Universidad de Cundinamarca; 2016.

26. Martínez J, Romero J. Aproximación a la entomofaúna desde dos tipos de orquídeas con ubicación en la reserva de Quininí. Folios Humanidades y Pedagog. 2016;1:21-36

27. Galvis W. Nineteen new species of Amphidraus Simon, 1900 (Salticidae: Euophryini) from Colombia, with comments about their conservation. Zootaxa. 2017;4286:1

28. Buitrago-Méndez J, López-Herrera L. Síndromes de dispersión de diásporas de las especies arbustivo y arbóreas de tres tipos de coberturas del Parque Natural Quininí, municipio de Tibacuy, Cundinamarca, Colombia. Rev Biodivers Neotrop. 2015;5:7-15.

29. Nieto J, Sierra M. Valoración económica de los servicios ambientales del Cerro Quinini ubicado en Tibacuy. Cundinamarca. Boletín Semillas Ambient. 2015;9:71-3.

30. Peña-Torres J. Análisis florístico del bosque de roble (Quercus humboldtii) Bonpl. (Fagaceae) de la Reserva Protectora Forestal Quininí, municipio de Tibacuy, Cundinamarca [Internet]. Universidad Nacional de Colombia, Sede Bogotá.; 2016. Available from: https://www.researchgate.net/publication/331 722876

31. Salas R, Tapias M. Tibacuy: un sitio arqueológico de frontera entre grupos indígenas del altiplano cundiboyacense y el valle medio del Magdalena. Boletín Arqueol. 2000;15:1-107.

32. Guerrero F. Aproximación a las experiencias temporales y espaciales de una comunidad campesina de la provincia del Sumapaz (Tibacuy -

Cundinamarca). Facultad de Ciencias Humanas: Universidad Nacional de Colombia; 2002.

33. Ramírez G. Las dinámicas políticas y territoriales panches ante la presencia hispana: diálogos entre el registro documental y arqueológico. [Buenos Aires, Argentina.]: Facultad de Ciencias Sociales Universidad Nacional del Centro de la Provincia de Buenos Aires; 2017.

34. Hernández M, Gonzalez Y, Moreno J, Moreno M, Solorzano G, Mican H, et al. Propuesta de articulación entre la UNAD, sector productivo y gubernamental de la región para favorecer la investigación y el desarrollo regional en la Zona Centro Bogotá Cundinamarca. Bogotá D.C; 2013.

35. Castellanos C. Evaluación de los recursos turísticos con vocación ecoturistica y caracterización de la demanda turística en las zonas de uso público de la Reserva Forestal Protectora del Cerro Quininí (Tibacuy-Cundinamarca). [Bogotá D.C]: Universidad Distrital Francisco José de Caldas; 2015.

36. Holdridge LR. Determination of world plant formations from simple climatic data. Science (80- ). 1947;105:367-8.

37. Corporación Autonoma Regional de Cundinamarca, Andina. O. Informe de producto N²: "Un documento de evaluación de la situación actual de administración y manejo de las áreas protegidas de carácter regional en la jurisdicción de la CAR." 2013.

38. Alcaldía Tibacuy C. Plan de Desarrollo Territorial 2016-2019: Porque Tibacuy avanza hacia el desarrollo sostenible. 2016.

39. Ministerio de Agricultura de Colombia. Acuerdo 0029 de julio de 1987. Minist. Agric. la República Colomb., 122 de Julio de 19871987 p. 5.

40. Margoluis R, Salafsky N. Measures of success: designing, managing, and monitoring conservation and development projects. Washington, DC: Island Press; 1998.

41. Drumond MA, Giovanett L, Guimarães A. Técnicas e Ferramentas participativas para a Gestão de Unidades de Conservação. Editora Arpa: Brasília; 2009.

42. International Society of Ethnobiology. International Society of Ethnobiology Code of Ethics [Internet]. Int. Soc. Ethnobiol. 2006. Available from: http:// ethnobiology.net/code-of-ethics/.
43. ESRI. ArcGIS Desktop: Release 10. Environmental Systems Research Institute:: Redlands, CA; 2017.

44. Ceríaco L, Marques M, Madeira N, Vila-Viçosa C, Mendes P. Folklore and traditional ecological knowledge of geckos in Southern Portugal: implications for conservation and science. J Ethnobiol Ethnomed. BioMed Central Ltd; 2011;7:1-9.

45. Fita D, Neto E, Schiavetti A. "Offensive" snakes: cultural beliefs and practices related to snakebites in a Brazilian rural settlement. J Ethnobiol Ethnomed. 2010;6:1-13.

46. Morúa A. La participación comunitaria en la gestión ambiental. Rev Venez Econ y Ciencias Soc. 2010;16:125-35.

47. Ruiz-Mallén I, Schunko C, Corbera E, Rös M, Reyes-García V. Meanings, drivers, and motivations for community-based conservation in Latin America. Ecol Soc. 2015;20:1-14.

48. Hart D, Sussman R. Man the hunted: primates, predators, and human evolution, expanded edition. Expanded Edition. 2008.

49. Coss R, Cavanaugh C, Brennan W. Development of snake-directed antipredator behavior by wild white-faced capuchin monkeys: III. the signaling properties of alarm-call tonality. Am J Primatol. 2019:81:1-10.

50. Lynch J. El contexto de las serpientes de Colombia con un análisis de las amenazas en contra de su conservación. Rev la Acad Colomb Ciencias Exactas, Físicas y Nat. Scielo. 2012;36:435-49.

51. Allen ER, Neill WT. Effect of marine toad toxins on man. Herpetologica. 1956:12:150-1.

52. Lim TH, Leitch IM, Boura AL, Read MA, Walters WA. Effects of Bufo marinus skin toxins on human fetal extracorporeal blood vessels. Toxicon. 1997;35: 293-304.

53. Roberts BK, Aronsohn MG, Moses BL, Burk RL, Toll J, Weeren FR. Bufo marinus intoxication in dogs: 94 cases (1997-1998). J Am Vet Med Assoc. 2000:216:1941-4.

54. Barbosa CM, Medeiros MS, Riani-Costa CCM, Camplesi AC, Sakate M. Toad poisoning in three dogs: case reports. J Venom Anim Toxins Incl Trop Dis. 2009;15:789-98.

55. Hernández-Rebollo E, Duque-Carrasco FJ, Zaragoza-Bayle C, Pérez-López M. Toad poisoning in dogs from SW Spain: too many cases in a few days! Rev Port Ciências Veterinárias. 2015;110:116-9.

56. Johnnides S, Green T, Eubig P. Toad Intoxication in the dog by Rhinella marina: the clinical syndrome and current treatment recommendations. J Am Anim Hosp Assoc. 2016;54:205-2011.

57. Letnic M, Webb JK, Shine R. Invasive cane toads (Bufo marinus) cause mass mortality of freshwater crocodiles (Crocodylus johnstoni) in tropical Australia. Biol Conserv. 2008;141:1773-82

58. Beckmann C, Shine R. Impact of invasive cane toads on Australian birds. Conserv Biol. 2009;23:1544-9.

59. Hayes RA, Crossland MR, Hagman M, Capon RJ, Shine R. Ontogenetic variation in the chemical defenses of cane toads (Bufo marinus): toxin profiles and effects on predators. J Chem Ecol. 2009;35:391-9.

60. Rodríguez-Vargas A, Rodriguez-Buitrago J, Diaz GJ. Comportamiento general de los accidentes provocados por animales venenosos en Colombia, 20062010. Rev salud pública. 2012;14:1001-9.

61. Diaz J, Jaramillo V. Incidencia y descripción geográfica de accidentes ofídicos en Colombia reportados al Sistema Nacional de Vigilancia en Salud Pública - SIVIGILA 2014-2016 [Internet]. Universidad de Ciencias Aplicadas y Ambientales - U.D.C.A.; 2019. Available from: https://repository.udca.edu.co/ bitstream/11158/1377/1/INCIDENCIA Y DESCRIPCION GEOGRAFICA DE ACCIDENTES OFIDICOS 2014- 2016.pdf.

62. Martínez G, Barboza G. Natural pharmacopoeia used in traditional Toba medicine for the treatment of parasitosis and skin disorders (Central Chaco, Argentina). J Ethnopharmacol. 2010:132:86-100.

63. Ávila-Nájera D, Mendoza G, Villarreal O, Serna-Lagunes R. Uso y valor cultural de la herpetofauna en México: Una revisión de las últimas dos décadas (1997-2017). Acta Zoológica Mex (nueva Ser. 2018:34:1-15.

64. Cortés-Gregorio I, Pascual-Ramos E, Medina-Torres S, Sandoval-Forero E, Lara-Ponce E, Piña-Ruíz H, et al. Etnozoología del pueblo Mayo-Yoreme en el Norte de Sinaloa: uso de vertebrados silvestres. Agric Soc y Desarro. 2013; 10:1-24.

65. Vallejo J, González J. Los anfibios en la medicina popular española, la farmacopea de Plinio y el Dioscórides. História Ciências Saúde Manguinhos. 2015;22:1283-319.

66. Altaf M, Umair M, Abbasi AR, Muhammad N, Abbasi AM. Ethnomedicinal applications of animal species by the local communities of Punjab, Pakistan. 
J Ethnobiol Ethnomed [Internet]. 2018;14. Available from: https://doi.org/ https://doi.org/10.1186/s13002-018-0253-4.

67. Lamadrid-Feris F, Coy-Barrera ED, Franco OL, Valencia JA, Arboleda VJW. Identification of compounds from white frog (Anura: Hylidae) cutaneous secretions with potential to be used in biotechnological processes. Pharmacologyonline. SILAE (Italo-Latin American Society of Ethnomedicine); 2015;2:118-23.

68. Qi J, Zulfiker AHM, Li C, Good D, Wei MQ. The development of toad toxins as potential therapeutic agents. Toxins (Basel). 2018;10:1-14.

69. Kolodziejczyk-Czepas J, Stochmal A. Bufadienolides of Kalanchoe species: an overview of chemical structure, biological activity and prospects for pharmacological use. Phytochem. Rev. 2017. p. 1155-71.

70. Siigur J, Aaspõllu A, Siigur E. Biochemistry and pharmacology of proteins and peptides purified from the venoms of the snakes Macrovipera lebetina subspecies. Toxicon. Elsevier Ltd; 2019. 158 p. 16-32.

71. Estévez-Haro M, Proaño-Morales A. Percepción y conocimientos de serpientes en una zona rural y urbana del Ecuador. Ethnoscientia. 2019;4:110.

72. Waldez F, Vogt R. Ecological and epidemiological aspects of snakebites in riverside communities of the lower Purus River, Amazonas, Brazil. Acta Amaz. 2009;39:681-92.

73. Gouveia R, Neto-Silva D, Sousa B, Novelli I. Evaluation of injuries caused by anthropic action in snakes from Brazil. Brazilian J Biol. 2015;75:535-40.

74. Alves R. Relationships between fauna and people and the role of ethnozoology in animal conservation. Ethnobiol Conserv. 2012;1:1-69.

75. Barlow J, Lennox GD, Ferreira J, Berenguer E, Lees AC, Mac Nally R, et al. Anthropogenic disturbance in tropical forests can double biodiversity loss from deforestation. Nature [Internet]. Nature Publishing Group, a division of Macmillan Publishers Limited. All Rights Reserved.; 2016;535:144. Available from: https://doi.org/https://doi.org/10.1038/nature18326.

76. Ruiz-Mallén I, Newing H, Porter-Bolland L, Pritchard DJ, García-Frapolli E, Méndez-López ME, et al. Cognisance, participation and protected areas in the Yucatan Peninsula. Environ Conserv. 2014:41:265-75.

77. Alkemade R, Reid R, van den Berg M, de Leeuw J, Jeuken M. Assessing the impacts of livestock production on biodiversity in rangeland ecosystems. Proc Natl Acad Sci. National Academy of Sciences; 2013;110:20900-20905.

78. Castillo L, Ladio A. Zootherapy and rural livestock farmers in semiarid Patagonia: the transfer of animal aptitudes for health. Ethnobiol Conserv. 2019;8.

79. Stave J, Oba G, Nordal I, Stenseth N. Traditional ecological knowledge of a riverine forest in Turkana, Kenya: implications for research and management. Biodivers Conserv. 2007;16:1471-89.

80. Braga $\mathrm{H}$, Schiavetti A. Attitudes and local ecological knowledge of experts fishermen in relation to conservation and bycatch of sea turtles (reptilia: Testudines), Southern Bahia, Brazil. J Ethnobiol Ethnomed [Internet]. Journal of Ethnobiology and Ethnomedicine; 2013:9:1. Available from: Journal of Ethnobiology and Ethnomedicine.

81. Martínez G. Use of fauna in the traditional medicine of native Toba (qom) from the Argentine Gran Chaco region: an ethnozoological and conservationist approach. Ethnobiol Conserv. 2013;2.

82. Bartholomew C, Abdullah M, Abdullah R, Clements G. Ethno-tourism: a review on natural resources use pattern by indigenous community in Peninsular Malaysia; 2017.

83. Vallejo-Betancur M, Páez V, Quan-Young L. Analysis of people's perceptions of turtle conservation effectiveness for the Magdalena River Turtle Podocnemis lewyana and the Colombian slider Trachemys callirostris in Northern Colombia: an ethnozoological approach. Trop Conserv Sci. 2018;11.

84. Jiménez-Liso M, Hernández-Villalobos L, Lapetina J. Dificultades y propuestas para utilizar las noticias científicas de la prensa en el aula de ciencias. Rev Eureka sobre Enseñanza y Divulg las Ciencias. 2010;7:107-26.

85. Sánchez-Mora AM. La Divulgación de la Ciencia como Literatura. Dirección general de divulgación en la ciencia, Universidad Nacional Autónoma de México.; 2000

\section{Publisher's Note}

Springer Nature remains neutral with regard to jurisdictional claims in published maps and institutional affiliations.

\section{Ready to submit your research? Choose BMC and benefit from:}

- fast, convenient online submission

- thorough peer review by experienced researchers in your field

- rapid publication on acceptance

- support for research data, including large and complex data types

- gold Open Access which fosters wider collaboration and increased citations

- maximum visibility for your research: over $100 \mathrm{M}$ website views per year

At BMC, research is always in progress.

Learn more biomedcentral.com/submissions 